\title{
Lausunnonantajat vuonna 2018
}

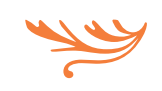

Vuonna 2018 Aikuiskasvatuksessa julkaistiin

12 vertaisarvioitua tiedeartikkelia. Lisäksi toimituskunta

käsitteli useita artikkelikäsikirjoituksia. Kiitämme

lämpimästi lausunnonantajia!

Ahola Sakari, VTT, dosentti, Koulutussosiologian tutkimuskeskus RUSE, Turun yliopisto

Antila Juha, VTL, kehittämispäällikkö, Suomen Ammattiliittojen Keskusjärjestö SAK

Collin Kaija, KT, yliopistotutkija, dosentti, kasvatustieteiden laitos, Jyväskylän yliopisto

Hakkarainen Kai, KT, professori, kasvatustieteellinen tiedekunta, Helsingin yliopisto

Henttonen Elina, KTT, toimitusjohtaja, Valtaamo Oy

Hirvilammi Tuuli, VTT, tutkijatohtori, Kokkolan yliopistokeskus Chydenius, Jyväskylän yliopisto

Hirvonen Helena, YTT, yliopistotutkija, yhteiskuntatieteiden ja filosofian laitos, Jyväskylän yliopisto

Holma Katariina, FT, professori, kasvatustieteen tiedekunta, Oulun yliopisto

Häkli Jouni, HT, professori, aluetiede, Johtamiskorkeakoulu, Tampereen yliopisto

Kaisto Jani, YTM, sosiologia; YTM, sosiaalityö, psykoterapeutti

Kallo Johanna, KT, tutkijatohtori, dosentti, kasvatustieteiden laitos, Turun yliopisto

Korhonen Maija, PsT, yliopistonlehtori, psykologian oppiaine, kasvatustieteiden ja psykologian osasto, Itä-Suomen yliopisto

Korvajärvi Päivi, YTT, professori emerita, yhteiskuntatieteiden tiedekunta, Tampereen yliopisto

Lakkala Keijo, YTM, tohtorikoulutettava, yhteiskuntatieteiden ja filosofian laitos, Jyväskylän yliopisto

LaPointe Kirsi, KTT, yliopistonlehtori, College of Education \& Human Development, Western Michigan University; kouluttaja, Valtaamo Oy

Mankkinen Teija YTT, erityisasiantuntija, sisäministeriö

Maunula Minna, KT, yliopistonopettaja, Kokkolan yliopistokeskus Chydenius Moore Erja, YTT, vapaa tutkija

Muhonen Reetta, YTT, yliopistotutkija (on leave); tutkijatohtori,

Higher Education Group, johtamisen ja talouden tiedekunta,

Tampereen yliopisto 
Naskali Päivi, KT, professori, kasvatustieteiden tiedekunta, Lapin yliopisto

Nevala Arto, FT, dosentti, yliopistonlehtori, historia- ja maantieteiden laitos, Itä-Suomen yliopisto

Nikkola Tiina, VTM, KT, FM, yliopistonopettaja, opettajankoulutuslaitos, Jyväskylän yliopisto

Paakkari Antti, VTM, väitöskirjatutkija, kasvatustieteellinen tiedekunta, Helsingin yliopisto

Palonen Mira, TtT, yliopisto-opettaja, hoitotiede, yhteiskuntatieteiden tiedekunta, Tampereen yliopisto

Palonen Tuire, KT, VTL, dosentti, opettajankoulutuslaitos, Turun yliopisto

Paloniemi Susanna, KT, yliopistonlehtori, kasvatustieteiden laitos, Jyväskylän yliopisto

Pasanen Heikki, FT, yliopettaja emeritus

Toiviainen Hanna, FT, apulaisprofessori, kasvatustieteiden tiedekunta, Tampereen yliopisto

Wallin Aila, KM, väitöskirjatutkija, organisaatiokonsultti, Awailable Consulting

Vanhalakka-Ruoho Marjatta, PsT, professori emerita, ohjauksen koulutus, Itä-Suomen yliopisto

Varjo Janne, FT, apulaisprofessori, koulutussosiologian ja -politiikan tutkimusyksikkö KUPOLI, kasvatustieteellinen tiedekunta, Helsingin yliopisto

\section{Refereepolitiikka}

Aikuiskasvatukseen tarjotut tiedeartikkelit käsitellään anonyymeina ja lähetetään mahdollisten muutospyyntöjen jälkeen kahdelle ulkopuoliselle asiantuntijalle arvioitavaksi. Arvioitsijat pysyvät kirjoittajille anonyymeinä, eikä kirjoittajan henkilöllisyyttä paljasteta arvioitsijoille.

Arvioinnin tavoite on antaa kirjoittajalle ehdotuksia ja neuvoja artikkelin parantamiseksi. Hyödyllisintä on rehellinen, kriittinen, käytännöllinen ja kannustava palaute. Referee arvioi seuraavia seikkoja:

- tutkimusaiheen merkityksellisyys, kiinnostavuus ja tärkeys

- kirjoittajan asiantuntemus
- tutkimusasetelma ja -menetelmät, lähdeaineisto, tutkimuksen toteutus ja käytetty tutkimuskirjallisuus suhteessa tutkimuskysymykseen

- tieteellinen taso

- sisällöllinen arvo ja uutuusarvo

- argumentoinnin vakuuttavuus

- kokonaisuus suhteessa otsikon ja aloituksen asettamiin odotuksiin

- esitystavan johdonmukaisuus

- luettavuus ja selkeys

- kuvioiden ja taulukoiden toimivuus. 